\title{
Managerial Judging and the Evolution of Procedure
}

\author{
E. Donald Elliott $\dagger$
}

Pandas don't have thumbs. At least, they don't have real thumbs. Instead, they have funny little extensions of their wrist bones that they use to strip the shoots off bamboo branches. They look like thumbs, and they work like thumbs-at least they work well enough that not many pandas starve. But technically only primates have real thumbs, with bones and muscles opposed to the fingers.

Evolutionary theorist Steven Jay Gould draws a number of lessons from the panda's "thumb." The one relevant here is that evolution is not infinitely malleable. Evolutionary processes work by modifying existing structures until they become capable of performing new functions. Hence, the panda's "thumb" -an elongated wrist bone that can do some, but not all, of the things a real thumb can do.

I hope to convince you that the procedural techniques grouped together under the rubric "managerial judging" have a lot in common with the panda's "thumb." This kind of analogy is not new. ${ }^{2}$ At the end of the first chapter of The Common Law, for example, Oliver Wendell Holmes, Jr. wrote:

$\dagger$ Professor of Law, Yale Law School.

I gratefully acknowledge the financial support of the American Bar Association Section of Litigation, the Center for Public Resources, the Yale Law School Civil Liability Program, the Houston Foundation, AT\&T, and the General Electric Foundation in the preparation of this and the other papers in the symposium.

1 See Stephen Jay Gould, The Panda's Thumb: More Rerlections in Natural HisTORY 21-24 (1980).

2 For a broader discussion of the biological analogy, see Elliott, The Evolutionary Tradition in Jurisprudence, 85 CoLum. L. REv. 38 (1985). 
[J]ust as the clavicle in the cat only tells of the existence of some earlier creature to which a collar-bone was useful, precedents survive in the law long after the use they once served is at an end and the [original] reason for them has been forgotten .... [A]s the law is administered by able and experienced men, who know too much to sacrifice good sense to a syllogism, it will be found that, when ancient rules maintain themselves .... new reasons more fitted to the time have been found for them, and that they gradually receive a new content, and at last a new form, from the grounds to which they have been transplanted. ${ }^{3}$

Elsewhere, Holmes suggests that legislatures, too, work primarily by adapting existing legal structures to perform new functions.*

This creative aspect of legal evolution is often overlooked. For example, Professor Resnik has written that "[t]he history of procedure is a series of attempts to solve the problems created by the preceding generation's procedural reforms." There is much truth in what Professor Resnik says, but the tone is too pessimistic. For her statement does not take into account fully the creative forces that can be set loose in the law when structures created to solve one set of problems provide resources that can be used to address new issues.

My thesis is that the evolution of managerial judging techniques is an illustration of an evolutionary process in the law which adapts existing structures to perform new functions-like the panda's "thumb," or the common law precedents to which Holmes referred. ${ }^{6}$ The first two sections of this article are an effort

3 Oliver Wendrll Holmes, JR. The Common Law 31-32 (M. Howe ed. 1963). Holmes was not the first to describe the phenomenon of the growth of law through adaptation of existing legal forms to new purposes. Maine wrote about the process in the mid-nineteenth century. See Henry Sumner Maine, Ancient Law: Its Connection with the Eardy History of Society and its Relation to Modern Ideas 24-27 (Beacon ed. 1963) (1st ed. London 1861). Maine's term for this phenomenon-"legal fictions"-carries the unfortunate implication that the process is one of conscious innovation. I prefer Holmes' evolutionary metaphors because they suggest the effect of unconscious processes on legal change. See Elliott, supra note 2 , at 54-55.

- The difference between evolution in common law and legislation is that "continuity with the past is only a necessity and not a duty" in the legislative field. Holmes, Law in Science and Science in Law, 12 HARv. L. REv. 443, 444 (1899). But even in legislation, "continuity ... limits the possibilities of our imagination, and settles the terms in which we shall be compelled to think." Id. at 444.

- Resnik, Precluding Appeals, 70 Cornell L. Rev. 603, 624 (1985).

- The analogy between biological evolution and the growth of procedure is not perfect, of course. Like all analogies, it brings certain features into sharper focus only at the price of suppressing or distorting others. But I do maintain that an understanding of the evolution 
to define what is meant by "managerial judging" and to understand the reasons why it developed. They conclude that the essence of managerial judging is ad hoc action by judges to impose costs on lawyers, and that managerial judging is a response to a fundamental design flaw in the Federal Rules of Civil Procedure: the lack of incentives for litigants to narrow issues for trial. The third section argues that in recent years, the functions performed by managerial judging have shifted. Originally created as a set of techniques to narrow issues for trial, managerial judging has recently become a set of techniques for inducing settlements.

However, a theory of the evolution of managerial judging that merely described what managerial judging is and why it developed would be unsatisfactory. Civil procedure, like most of the law today, develops not only through a process of common law evolution, but also through conscious design choices made by legislators and rulemakers. It is time to evaluate the "panda's thumb" of managerial judging, and to ask whether we can design something better. Thus, the final section of this article presents a critical assessment of managerial judging and a statement of the directions that the future reform of civil procedure should take. The essential recommendation is that we should think about civil procedure less from the perspective of powers granted to judges, and more from the perspective of incentives created for lawyers and clients. Our current system of civil litigation creates perverse incentives for lawyers, and then relies on judges to police litigant behavior through techniques like managerial judging. If we are not satisfied with the results, we should redesign the system to provide direct incentives for appropriate behavior.

\section{A Definition of Managerial Judging}

\section{A. The Rhetoric}

Since the early 1950s, special management procedures have been advocated for processing antitrust and other "complex" cases. ${ }^{7}$ In recent years, however, many judges have advocated ex-

of procedure is not merely an academic exercise. The acid test of an evolutionary theory of law is not whether it is true, but whether it is useful. See Elliott, supra note 2, at 92-93. If we are to improve our ability to do managerial judging, we must improve our collective understanding of what judicial management is, and what its functions are. One way to understand managerial judging better is to put it in perspective by understanding how and why it has developed and in what directions it is likely to move in the future.

3 See Handbook of Recommended Procedures for the Trial of Protracted Cases, 25 F.R.D. 351 (1960) (adopted by the Judicial Conference of the U.S. in March 1960); Report 
tending these techniques to civil litigation generally, and it has become common to refer to them as "managerial judging." The specific techniques advocated by self-styled managerial judges vary so widely that it is not clear what, if anything, they have in common. Suggestions range from highly informal status conferences (sometimes off the record in chambers) ${ }^{9}$ to structured regimes relying on formal pretrial conferences ${ }^{10}$ or on extensive paper filings. ${ }^{11}$

What makes the managerial judging movement coherent is not so much the existence of specific techniques on which all managerial judges agree. Rather, managerial judges are distinguished by common themes in their rhetoric. Managerial judges believe that the system does not work; that something must be done to make it work; and that the only plausible solution to the problem is ad hoc procedural activism by judges. ${ }^{12}$

The diagnosis. Advocates of managerial judging point to several indications that action is needed. They cite the growing caseload of the federal judiciary. ${ }^{13}$ They express concern with the changing nature of civil litigation: new causes of action have expanded the judicial role and challenged the limits of judges to reform institutions and to remedy social ills. ${ }^{14}$ More recently, the rising cost of civil litigation has come to the fore as a major

on Procedure in Anti-Trust and Other Protracted Cases, 13 F.R.D. 62, 83 (1953) (adopted by the Judicial Conference of the U.S. on Sept. 26, 1951) (commonly called The Prettyman Report).

- See, e.g., Costantino, Judges as Case Managers, Trial, March 1981, at 56; Peckham, The Federal Judge as a Case Manager: The New Role in Guiding a Case from Filing to Disposition, 69 CalIr. L. REv. 770 (1981). For an analysis of managerial judging, see Resnik, Managerial Judges, 96 HaRv. L. Rev. 374 (1982).

- See, e.g., Costantino, supra note 8, at 58; see also Resnik, supra note 8, at 387-90 (discussing two hypothetical cases).

10 See, e.g., Krupansky, The Federal Rules are Alive and Well, Litigation, Fall 1977, at 10, 12-13 (describing formal pretrial conferences, conducted in open court on the record).

13 See, e.g., Richey, A Federal Trial Judge's Reflections on the Preparation for and Trial of Civil Cases, 52 IND. L.J. 111 (1976) (discussing pleadings and pretrial filings).

${ }^{22}$ See Peckham, A Judicial Response to the Cost of Litigation: Case Management, Two-Stage Discovery Planning and Alternative Dispute Resolution, 37 RUTGERs L. REv. 253, 264-65 (1985) ("Professor Resnik places the onus of responsibility for the orderly and prompt disposition of litigation with the bar, whereas I place that responsibility equally, if not primarily, on the shoulders of the judge.").

13 See, e.g., Costantino, supra note 8, at 56-57.

${ }^{24}$ See, e.g., Kirkham, Complex Civil Litigation-Have Good Intentions Gone Awry?, 70 F.R.D. 199, 209 (1976) (arguing that the jury system is a limit on the institutional capacity of courts to adjudicate complex cases, and advocating abolition of the right to a jury in such cases); Statement of E. Donald Elliott before the Standing Committee on Rules of Practice and Procedure, Washington, D.C., Oct. 16, 1981 (on file with The University of Chicago Law Review). 
justification for managerial judging. ${ }^{15}$

For now, it is not important to debate whether any of the purported justifications for managerial judging are valid. ${ }^{16}$ What is more important is to recognize that the advocates of managerial judging are making a fundamental critique of the existing procedural regime. The present structure of civil procedure, they say, necessarily fails to achieve its self-proclaimed goal of "the just, speedy, and inexpensive determination" of controversies if left to its own devices. ${ }^{17}$ At base, the advocates of managerial judging claim that the Federal Rules of Civil Procedure do not work. Yet despite the growing acceptance of managerial judging, the fact that its advocates are challenging the adequacy of the Rules has rarely been noticed. ${ }^{18}$ In the long run, their implicit critique of the Rules may be far more important than their specific procedural innovations.

The cure. The claim that ad hoc action by judges is the remedy of choice for the ills afflicting civil litigation is not only made explicitly in the Manual for Complex Litigation, ${ }^{19}$ but it is implicit in the image of the judge as "manager." A manager is a decisionmaker, an executive. The metaphor casts the judge, not the litigants or their lawyers, as making the executive decisions in litigation.

In itself, there is nothing remarkable about portraying a judge as a decisionmaker. The business of judging is the business of deciding. But by conceiving of certain decisions as "managerial" decisions, rather than legal decisions, the concept of managerial judging posits a kind of decisionmaking that is different from what we traditionally expect of judges. Proponents of managerial judging

1s See Peckham, supra note 12, at 253-54. See generally ABA Action Comm'N to REduce Court Costs and Delay, Attacking Litrgation Costs and Deinay (1984) (discussing the costs of civil litigation) [hereinafter cited as ABA REPORT].

16 For a spirited argument that none of the factors commonly cited to justify the need for increased judicial management has in fact been demonstrated, see Resnik, supra note 8, at $417-24$.

17 FED. R. Crv. P. 1.

18 Perhaps the oversight is due in part to the fact that the advocates of managerial judging tend to be active federal judges, who need immediate solutions. Their rhetoric may be limited to what can be done within the general structure established by the Rules, but their critique has deeper implications.

19 [T] he propriety, if not the necessity, of judicial control to promote the efficient conduct of the litigation . . . stems from an awareness that the tensions between an attorney's responsibilities as an advocate and as an officer of the court frequently are aggravated in complex litigation and that the tactics of counsel may waste time and expense if the judge passively waits until problems have arisen.

Manual ror Complex Litigation, Second § 20.1 (1985). 
generally overlook this distinction. Judge Robert F. Peckham writes, for example:

Admittedly, in limiting the scope of discovery, setting schedules, and narrowing issues, the [managerial judge] restricts somewhat the attorneys' freedom to pursue their actions in an unfettered fashion and eliminates entirely some theories or lines of inquiry. Motions to dismiss some claims or for partial summary judgment similarly may result in the drastic alteration of the contours of a lawsuit, yet we do not question the legitimacy of judges' deciding such motions. ${ }^{20}$

With all due respect, Judge Peckham's statement reflects both a fundamental insight and a fundamental oversight. The insight is that managerial judging is a functional substitute for motions to dismiss or for partial summary judgment. The oversight is the failure to acknowledge that decisions to narrow issues through managerial techniques are based on fundamentally different kinds of considerations from those that justify granting traditional motions to narrow issues. A judge who narrows the issues in a case by granting a motion to dismiss or for partial summary judgment must act according to law and provide a reasoned justification, subject to appellate review. The idea that decisions to foreclose certain issues and lines of inquiry are "managerial," on the other hand, implies that these decisions are not based on the legal merits of the parties' positions.

The concept of judge as manager is significant, however, not only for the kinds of reasons it excludes (legal decisions on the merits), but also for the kinds of reasons it implicitly includes. The prototypical "managerial" decision is one that allocates limited resources. The notion that judges are to decide certain issues as "managers" implies that they must take into account the hard economic reality that procedural resources are limited and that decisions must be made on a sound, "business-like" basis as to which opportunities to pursue and which to pass by.

The programs proposed by the proponents of managerial judging have, by and large, been true to the implications of the image of judge as "manager." Stripped to their essentials, the techniques of managerial judging ration a scarce good-the procedural moves available to litigants under the Federal Rules of Civil Procedure. According to the advocates of managerial judging, this good is offered to its consumers (lawyers) at well below its true social cost;

20 Peckham, supra note 12, at 262. 
therefore they consume too much of it. The essential function of managerial judging is to increase the price of procedure. ${ }^{21}$ One can in fact define managerial judging as the selective imposition by judges of costs on lawyers for the purpose of rationing the use of procedures available under the Federal Rules of Civil Procedure. ${ }^{22}$

Managerial judging techniques accomplish their goal of increasing the costs to lawyers of exercising their clients' procedural rights in a number of different ways, some more explicit than others. For example, local rules in some courts limit the number of interrogatories that may be served without special leave of court. ${ }^{23}$ Other techniques are more subtle. The United States District Court for the Eastern District of New York now requires that attorneys review interrogatories "to ascertain that they are applicable to the facts and contentions of the particular case."24 This im-

${ }^{21}$ Cf. Note, Discovery Abuse Under the Federal Rules: Causes and Cures, 92 YaLE L.J. $352,356-60$ (1982) ("discovery abuse" occurs because parties can impose large costs on their opponents in litigation at only small costs to themselves).

${ }^{22}$ The approach taken in the text makes a sharp distinction between costs to lawyers and costs to clients. Most previous analyses of the incentives in litigation have not done so, because they have used the concept of a "party," see, e.g., id., which obscures the fact that lawyers and clients are not always affected in the same way. In fact, it would not be much of an overstatement to say that the premise behind managerial judging is that costs to clients can be decreased by increasing certain costs to lawyers.

Some of the extra costs imposed on lawyers by managerial judging can be passed on to clients, but a large portion are borne by lawyers. For lawyers as a group, the extent to which extra costs can be passed along to clients is determined by supply and demand conditions in the market for legal services. See generally PaUL SAMUELSON, Economics: AN INTRODUctory ANALYsis 389-90 (10th ed. 1976) (economic theory of the incidence of a tax). However, from the standpoint of an individual lawyer and client in a particular case, the degree to which additional costs of a specific type can be passed on will be determined in the short run by the terms of the contract between them. Most contracts for legal services are based on hourly rates or contingent fees. Neither standard form of contract permits a lawyer to charge a premium for time spent at 2 a.m. rather than during regular business hours. Thus, for example, if a managerial judge takes actions that compress the time available before trial, the increased costs to lawyers of working at 2 a.m. rather than during regular business hours cannot be passed along to clients to an appreciable degree.

Many of the most effective techniques of managerial judging impose costs which, because of their nature, fall heavily on lawyers (rather than being passed on to clients) under the prevailing forms of contracts for legal services. Over time, of course, lawyers may attempt to re-negotiate the standard contracts to try to pass more of these costs to clients. However, to the extent that managerial judges are sufficiently innovative in imposing costs of types that were not foreseen when contracts for legal services were entered into, judges can probably succeed in imposing a significant portion of the incremental costs on lawyers.

23 See, e.g., Federal Local Rule 7.4 (S.D. Ga.), in 1 Federal Local Court Rules for Crvin and Admiralty Proceendngs (Callaghan 1984) (presumptive limit of 25 interrogatories); Federal Local Rule 8.2.1 (C.D. Cal.), in 1 id. (presumptive limit of 30 interrogatories); Federal local Rule 17(d) (D. Kan.), in 1 id. (same).

24 U.S. District Court for the Eastern District of New York, Standing Orders of the Court on Effective Discovery in Civil Cases, Standing Order 15, 102 F.R.D. 339, 351-52 
poses a modest additional burden on attorney time and convenience: litigators must tailor their standard forms to a particular case.

A number of other managerial techniques also depend for their effectiveness on imposing costs in time and inconvenience as a condition of exercising procedural rights. The special masters in the AT\&T antitrust case, for example, required attorneys who wished to object to discovery through a claim of privilege to submit written evidence substantiating each element of the claim. The apparent result was that fewer privilege claims were asserted..$^{25}$ At one time, Judge Charles Richey's standard pretrial order required litigants to file detailed pretrial briefs identifying, among other things, all issues and "all facts which plaintiff [defendant] intends to prove at trial to sustain [defend against] each element of the claim for relief." ${ }^{28}$ Then, counsel for each of the parties was required to go through the opposing side's proposed findings of fact and conclusions of law, and to underline the disputed portions in red, the admitted portions in blue, and those portions deemed to be irrelevant in yellow. ${ }^{27}$ An extraordinarily high percentage of cases were settled just before counsel were required to get out their colored pencils. ${ }^{28}$

Another way to impose costs on attorneys is to impose sanctions for actions that a judge later finds are improper. ${ }^{29}$ However, the "present value" of sanctions will be discounted depending on how likely an attorney believes it to be that a judge will actually impose sanctions.

Perhaps the most important single element of effective managerial judging is to set a firm trial date. ${ }^{30}$ Limiting the amount of

(1984).

${ }^{2 s}$ Hazard \& Rice, Judicial Management of the Pretrial Process in Massive Litigation: Special Masters as Case Managers, 1982 AM. B. Found. Research J. 375, 400-01.

${ }^{26}$ Richey, supra note 11 , at 118.

27 Id. at 119.

28 Oral Statement of Judge Charles Richey, Seminar on the Art and Process of Trial Practice, Georgetown University Law Center, Washington, D.C., June 18, 1979.

20 See, e.g., Fed. R. CIv. P. 26(g) (sanctions against party seeking discovery); Fed. R. Crv. P. 37 (sanctions for failure to comply with discovery requests); National Hockey League v. Metropolitan Hockey Club, 427 U.S. 639, 643 (1976) (per curiam) (discussing the deterrent effect of sanctions); Pollack, Cutting the Fat from Pretrial Proceedings, 97 F.R.D. 319, 324 (1982) (discussing rule 26(g)); Note, The Emerging Deterrence Orientation in the Imposition of Discovery Sanctions, 91 HaRv. L. Rev. 1033, 1054 (1978) (considering the need for "punitive sanctions other than dismissal or default"); Comment, Sanctions Imposed by Courts on Attorneys Who Abuse the Judicial Process, 44 U. CHI. L. REv. 619 (1977) (discussing alternative sanctions, judicial and non-judicial).

so Peckham, supra note 12, at 258 n.13 ("Such firm dates motivate the parties to estab- 
time before trial establishes a "zero-sum game," in which part of the cost of working on one issue is the opportunity cost of not being able to work on other issues within the limited time available before trial. This creates incentives for attorneys to establish priorities and "narrow the areas of inquiry and advocacy to those they believe are truly relevant and material" and to "reduce the amount of resources invested in litigation." 31

In sum, techniques of managerial judging vary greatly in how they increase the price of exercising procedural rights in litigation. ${ }^{32}$ Nonetheless, they all depend on the same essential principle: if we increase the cost of something, we get less of it.

\section{B. The Debate}

Once the function of managerial judging is clear, it is easier to put the arguments pro and con into perspective. Opponents of managerial judging, eloquently led by Professor Resnik, object on several grounds to the practices employed by managerial judges. ${ }^{33}$ They argue that litigants are being forced, directly or indirectly, to abandon positions on the merits. To make matters worse, they say, judges are making discretionary procedural decisions early on that effectively close off lines of substantive inquiry without benefit of full development and consideration of the merits of the parties' positions. And the "managerial" decisions of these judges are largely immune from appellate review.

Issue narrowing. Certain aspects of the critique are undenia-

lish proper priorities rather than to pursue all potential arguments.").

s1 Report to the President and Attorney General of the National Commission for the Review of Antitrust Laws and Procedures, 80 F.R.D. 509, 535 (1979) (footnote omitted); see also Peckham, supra note 12, at 258 n.13.

${ }^{32}$ On the surface, a number of judicial management techniques are difficult to fit into the mold of increasing costs to lawyers, but generally the concept of "costs" is sufficiently elastic to accommodate them. For example, the common practice of appointing lead counsel or a steering committee in complex cases, see Manual for Complex Litigation, SEcond $\S 20.22$ (1985), is normally thought of as reducing litigation costs for clients. From the standpoint of an individual litigator, however, this arrangement makes it more difficult to pursue his or her own tactical or procedural judgments: doing so requires convincing the lead counsel or committee. Hence, the arrangement may be thought of as increasing costs to the individual lawyer.

A technique which is more difficult to assimilate to the concept of increasing costs to lawyers is some judges' practice of expressing their skepticism to counsel about the merits of particular arguments. See Resnik, supra note 8 , at 390 . This technique may be viewed as communicating that counsel risks incurring the judge's displeasure (a very considerable "cost" that will affect the lawyer in future litigation before that judge), or as a way of communicating that the argument is not likely to succeed, and hence, that the cost of engaging in the tactic outweighs the likely benefit.

${ }^{33}$ See Resnik, supra note 8, at 424-31 \& passim. 
bly true. When a managerially-minded judge limits discovery to certain issues or selects a trial date only a few months away, ${ }^{34}$ the judge forecloses the development of issues. Sometimes the actions of the managerial judge determine directly which issues are foreclosed; more often, the judge's action forces counsel to make that decision. But in either case, issues are foreclosed. Indeed, if managerial judging does not have the effect of restraining lawyers' freedom of action, it is not effective.

Newer "managerial" techniques such as the mini-trial" and the summary jury trial ${ }^{36}$ appear to address the critics' concern that litigants are being forced to narrow the issues against their will. Like the "classic" techniques of managerial judging, mini-trials and summary jury trials force litigants to narrow the litigation to essential issues. However, mini-trials and summary jury trials accomplish the goal of narrowing the issues by means that some people find more acceptable than "classic" managerial judging. The procedures employed in mini-trials and summary jury trials resemble the procedures traditionally accepted as legitimate for resolving issues on the merits. And the narrowing of issues as a result of a mini-trial or summary jury trial is nominally voluntary, in the sense that litigants remain free to insist on a full trial. ${ }^{37}$

Effectiveness. Some opponents of managerial judging, led by Professor Resnik, contend that managerial judging is ineffective-or at least, that the effectiveness of managerial judging has not been demonstrated. ${ }^{38}$ Here I must respectfully part company with the loyal opposition. Both my personal experience as a litigator and the available published data ${ }^{38}$ convince me that at least

"See, e.g., Peckham, supra note 12, at 268.

ss See CPR Legal Program Mini-Trual Workbook (1985); Hoellering, The MiniTrial, ARB. J., Dec. 1982, at 48; Olson, Dispute Resolution: An Alternative for Large Case Litigation, Litigntion, Winter 1980, at 22; Parker \& Radoff, The Mini-Hearing: An Alternative to Protracted Litigation of Factually Complex Disputes, 38 Bus. LAw. 35 (1982).

st See Lambros, The Summary Jury Trial and Other Alternative Methods of Dispute Resolution, 103 F.R.D. 461 (1984); Lambros \& Shunk, The Summary Jury Trial, 29 CLEv. ST. L. Rev. 43 (1980); Slonim, One Judge's Invention: Summary Jury Trials, 67 A.B.A. J. 24 (1981).

${ }^{37}$ For a critical examination of this claim of legitimacy and non-arbitrariness, see Posner, The Summary Jury Trial and Other Methods of Alternative Dispute Resolution: Some Cautionary Observations, 53 U. CH. L. Rev. 366 (1986).

s* See, e.g., Resnik, supra note 8 , at 417-24.

3" See, e.g., ABA Report, supra note 15, at 3-22 (study of the Economical Litigation Project in Campbell County Circuit Court, Kentucky); P. Connolly, E. Holleman \& M. Kuhlman, Judicial. Controls and ths Crvil. Litigative Prockss: Discovery 52-76 (1978) (study of discovery in six metropolitan federal district courts); STEVEN FLANDERS, CASE MANagement and Court Management in Unitzd States District Courts 17-43 (1977) (same). 
some managerial techniques are effective in reducing the amount of time and effort invested in processing a given case. ${ }^{40}$ There are also compelling logical arguments that managerial judging is effective in this limited sense. There is no reason to assume that lawyers are immune from Parkinson's Law that work tends to expand to fill the time available; ${ }^{11}$ on the contrary, the fact that many lawyers are paid by the hour suggests that our profession may be more susceptible to this principle than most. ${ }^{42}$

Arbitrariness. Focusing on the effectiveness, rather than the fairness, of managerial judging diverts the debate from the more interesting and ultimately more important issue of the ad hoc and potentially arbitrary nature of managerial judging. There is an undeniable potential for arbitrariness in any procedure that forecloses issues in litigation without adequate consideration of their merit.

The potential for arbitrariness inherent in managerial judging

Professor Resnik criticizes the Flanders study for not taking into account the added costs to judges and litigants of managerial judging. Resnik, supra note 2 , at $422, n .182$. This criticism is valid insofar as it is intended to point out that the advocates of managerial judging have not proven that managerial judging produces net benefits in excess of its costs. On the other hand, the Flanders study is significant in that it shows that managerial judging does work, in the sense that it does reduce costs and delay in individual cases. I do not understand Professor Resnik to deny this point, but rather to assert that since we cannot measure the costs of managerial judging, we do not yet know whether the benefits, as shown by the Flanders study, exceed the costs.

There is a significant difference between maintaining that managerial judging does not work at all, and maintaining that while we know it works, we don't yet know whether it works well enough for the game to be worth the candle. Among other things, it is likely that the costs of managerial judging vary widely among different techniques, and thus for some subset of managerial judging techniques it remains plausible that net benefits may exist (although no one has yet proven or disproven that hypothesis). I do agree with Professor Resnik, however, that further research in this area is needed. Moreover, I think that it is important that we begin to analyze the effectiveness and costs of various techniques of managerial judging separately rather than lumping them together.

10 Of course, reducing the amount of time and effort devoted to processing a given case is not necessarily a good thing. That depends on whether one believes that the reduced cost of litigation is not offset by a decline in the quality of justice that may result. See Trubek, Sarat, Felstiner, Kritzer \& Grossman, The Costs of Ordinary Litigation, 31 UCLA L. REv. 72, 109-23 (1983) (assessing the value of "investment in litigation" from the standpoints of private parties and society).

41 C. Northcote Parkinson, Parkinson's Law and Other Studies in Administration 2 (1957).

42 See Pollack, Discovery-Its Abuse and Correction, 80 F.R.D. 219, 223 (1978) (blaming many excesses on a system in which "[h]ours are the criterion of pay"); Rosenberg, Discovery Abuse, LITIGATION, Spring 1981, at 8, 9-10 (advocating alternatives to hourly billing); Sofaer, Sanctioning Attorneys for Discovery Abuse Under the New Federal Rules: On the Limited Utility of Punishment, 57 ST. JoHN's L. REv. 680, 727-29 \& n.194 (1983) (describing abuse of discovery by both plaintiffs' and defendants' lawyers, in part due to hourly billing). 
was clearly demonstrated in a unique controlled experiment at the conference upon which this symposium is based. The participating judges were divided into separate workshop sessions, each of which was asked to propose approaches for managing the same hypothetical case. ${ }^{43}$ The reports from the workshops disclosed dramatic differences in the ways that individual judges would have handled the case. Based on her intuition that the case had little merit, one trial judge would have required thousands of plaintiffs to file individual, verified complaints-a move that would have made it all but impossible for the plaintiffs' lawyer to pursue the cases. On the other hand, another trial judge confronting exactly the same hypothetical case would have ordered the defendants to create a multi-million dollar settlement fund. ${ }^{44}$

Perhaps various judges' reactions would have differed as widely if they had been asked to rule on a point of law. But at least when judges make legal decisions, the parties have an opportunity to marshal arguments based on an established body of principles, judges are required to state reasons to justify their decisions, and appellate review is available. None of these safeguards is available when judges make managerial decisions.

It seems beyond serious debate, then, that discretionary managerial decisions may influence the outcome of litigation in ways that are arbitrary because judges act without the procedural safeguards that accompany decisions on the merits.

The advocates of managerial judging do not, by and large, deny the opponents' claims that the practices of managerial judges are ad hoc and therefore (by definition) potentially arbitrary. They concede that the discretionary powers of a managerial judge can be abused. ${ }^{45}$ But they plead in confession and avoidance that without managerial judging, the results would be worse. The procedural

\section{Review.}

13 The workshop problem discussed here is on file with The University of Chicago Law

" "A series of workshops provided a vivid illustration of how judges can take different approaches to the same case. . . . At one workshop session, Judge Susan Getzendanner (N.D. Ill.) . . . recommended the establishment of a $\$ 60$ million settlement fund up front ... . Another workshop featured a completely different solution, proposed by another federal judge. Orinda D. Evans (N.D. Ga.) expressed grave reservations about the validity of the plaintiffs' underlying claims and indicated that she would use procedural tools at her disposal to stall the litigation in order to promote settlements. Specifically, the judge said she would deny class certification and require all plaintiffs to submit individual complaints, pleaded with specificity." Graham, ADR Conference Airs Hopes-and Some Doubts, Legal Times, Oct. 14, 1985, at 4, cols. 3-4.

${ }^{4}$ See, e.g., Peckham, supra note 12, at 261-63 (acknowledging problems of impartiality); id. at 257 n.13 (implicitly acknowledging that judges sometimes set arbitrary case schedules). 
system, they say, is not capable of resolving disputes in a fair and timely manner unless judges take control and "exert firm and forceful supervision" of cases. ${ }^{46}$ Circuit Judge Jon Newman argues forcefully that reformers interested in a fair judicial system cannot look solely at "fairness" to the litigants in an individual case; rather, they must balance the individual litigant's interest in fairness against the competing interest in fairness shared by all other current and potential litigants. ${ }^{47}$

Conflicts between the rights of individuals and those of the community are difficult, if not impossible, to resolve in principle. Our legal system has generally taken a meliorative approach to such conflicts: accepting that some conflict between individual and community is inevitable, but attempting to devise techniques to minimize it.

\section{The Original Function of Managerial Judging}

From this perspective, managerial judging emerges as a stopgap-like the panda's "thumb." In an ideal world, perhaps we would not choose managerial judging as the best method of processing civil cases. But managerial judging may improve our ability to function with the limited resources available in the world we have.

What this perspective on managerial judging overlooks, however, is that "the world we have" in civil procedure is not the only possible world. In civil procedure at least, the "world we have" is an artificial world created by the structure of the Federal Rules of Civil Procedure and related statutes and decisions. While there has been much tinkering with particular rules since 1938, very little attention has been paid to the overall structure of incentives created by the Federal Rules.

In part, the oversight is due to the peculiar nature of the Rules. The Rules establish certain procedural forms-pleadings, discovery devices, motions for summary judgment, and the rest-which are available as building-blocks to be assembled by lawyers and judges into a procedure for a particular case. ${ }^{48}$ Because

1. Id. at 266.

47 Newman, Rethinking Fairness: Perspectives on the Litigation Process, 94 Yale L.J. 1643,1644 (1985).

${ }^{8}$ Cf. Cover, For James Wm. Moore: Some Reflections on a Reading of the Rules, 84 YALE L.J. 718 (1975) (arguing that the Rules are often erroneously treated as a limiting code, but that such rigidity is neither desirable nor necessary under the Rules). 
the Rules function as a series of "enabling grants" a comprehensive procedural code, it is difficult to relate problems to the structure established by the Rules as a whole.

However, the problem that managerial judging aims to solve is, at base, structural: it results from a fundamental imbalance in the Rules between the techniques available for developing and expanding issues and those for narrowing or resolving them prior to trial.

That the issue-narrowing capacity of the Federal Rules is emaciated can be brought into focus by recalling the predecessor system of "common law pleading." We all learned in law school about the old practice of pleading back and forth until a single issue was joined. ${ }^{\text {so }}$ The drafters of the Federal Rules understood well the frailties of this system, which required parties to narrow their contentions prior to developing a full understanding of the facts. Moreover, under a system which narrows issues based on common law pleadings, litigants' cases are likely to turn on procedural choices by counsel, rather than on the legal merit of a party's case.

The new system under the Federal Rules was supposed to be different. ${ }^{51}$ Through full discovery of the facts, lawyers were supposed to learn which of their contentions were supportable at trial and which were not. ${ }^{52}$ And if an occasional recalcitrant litigant refused to accept the results of discovery voluntarily, summary judgment was to be available to dispose of unsubstantiated claims prior to trial. ${ }^{58}$ Thus, as the framers envisioned their new system, the issue-narrowing function was to be performed not by pleading, but by discovery and summary judgment.

According to the proponents of managerial judging, it hasn't worked out that way. Without the intervention of a managerial judge, the incentive system which operates in discovery does not lead counsel to narrow issues voluntarily. ${ }^{54}$ Moreover, the discovery

10 Clark, Special Problems in Drafting and Interpreting Procedural Codes and Rules, 3 VAND. L. REv. 493, 496 (1950); see also id. at 499-500 (distinguishing the approach of the Field Code).

so See, e.g., J. Cound, J. Friendenthal, A. Miller \& J. Sexton, Civil Procedure: Cases and Materials 395 (4th ed. 1985).

s1 See Clark, Fundamental Changes Effected by the New Federal Rules, 15 Tenn. L. Rev. 551, 551 (1939); Clark \& Moore, A New Federal Civil Procedure II: Pleadings and Parties, 44 YALE L.J. 1291, 1294-99 (1935).

62 Sunderland, Discovery Before Trial Under the New Federal Rules, 15 TENN. L. Rev. 737, 738 (1939).

6s Id. at 755-57. See Fed. R. CIv. P. 56.

s4 See Sofaer, supra note 42 , at 728-29 (defense counsel cannot be relied on to check abuse by plaintiff' counsel); Note, supra note 21 , at 356-60, 373-74. 
sanctions added by the 1983 amendments ${ }^{55}$ do not change the underlying incentives in any fundamental way; they may actually make matters worse by imposing an additional layer of procedural resources that can be used by lawyers for tactical purposes.

The designers of the Rules also failed to appreciate that the primary technique they created for the involuntary narrowing of issues prior to trial-summary judgment-would prove largely inadequate to the task. Empirical studies have shown that summary judgment motions are made in only approximately four percent of all cases. ${ }^{56}$ Indeed, late in his life, Judge Charles Clark, the primary drafter of the Rules, himself reflected on the possible causes for the failure of rule 56 to achieve all that he and the other drafters had hoped for it. ${ }^{.7}$

This is not to say that summary judgment is never a useful tool of judicial management. On the contrary, in the hands of a skillful trial judge (and an understanding court of appeals), summary judgment-particularly partial summary judgment-can be a useful technique for narrowing issues in some instances. ${ }^{58}$ However, in general the combination of discovery and summary judgment has proved inadequate to narrow the issues in litigation prior to trial.

To be sure, the fault does not lie entirely in either the incentives of an adversary system or the structure of the Rules. In part, the tendency of disputes to expand to the limits of the parties' pocketbooks results from new forms of action and new jurisprudential styles which have made the set of potentially relevant "facts" almost limitless in some kinds of litigation. ${ }^{59}$ The fact remains, however, that the paucity and weakness of techniques available for narrowing issues on the merits is a fundamental design flaw of the Federal Rules of Civil Procedure.

Procedural reformers, however, rarely think of the Rules as a system of incentives. Because they perceive the Rules only as a

ss See FEv. R. Crv. P. 26(g).

${ }^{56}$ McLauchlan, An Empirical Study of the Federal Summary Judgment Rule, $6 \mathrm{~J}$. LEGAL Stud. 427, 451 (1977).

${ }^{87}$ See Clark, supra note 49 , at 502-03.

ss See Manual for Complex Litigation, Second $\$ 21.34$ (1985); Recommendations of the American College of Trial Lawyers on Major Issues Affecting Complex Litigation, 90 F.R.D. 207, 226-31 (1981).

Bo See, e.g., Sofaer, supra note 42 , at 722 (discussing the massiveness of discovery in cases involving "highly complex, political, and social issues"); cf. F. JAMES \& G. HAzArD, CiviL Procedure $\S 6.15$ at 211 (2d ed. 1977) (in a simple case involving a contract or automobile accident, "the subject matter of the action is itself fairly limited and this imposes some limits on discovery"). 
loose collection of techniques, it is always easier to suggest a "fix" for a particular problem by supplementing the Rules. The rise of managerial judging as an ad hoc way of narrowing issues to a manageable compass is an example of this process.

Ironically, our great reluctance to narrow issues prematurely on the merits has been a major factor in the evolution of managerial judging which may narrow issues capriciously. The stringent standards of rule 56 (and behind it, the seventh amendment) insist that issues can be disposed of on the merits prior to trial only if "there is no genuine issue as to any material fact." mary judgment and the other issue-narrowing tools available in the Rules are so difficult to use, issue-narrowing is increasingly being performed through managerial judging, without any formal procedures or safeguards for assessing the merit of the issues that are foreclosed. Litigants actually end up with less, not more, protection against arbitrariness. A further irony is that the use of managerial judging to narrow issues reintroduces two of the primary evils that the drafters of the Federal Rules were at pains to abolish-premature definition of issues, and outcomes based on preliminary procedural skirmishing rather than the legal merit of claims.

In the future, we need to find procedural techniques for narrowing issues that take into account the essential truth that information is a scarce and costly good that must inevitably be rationed. ${ }^{61}$ The question is not whether to ration the full development of facts in litigation, but how to do so as equitably as possible. The system created by the Federal Rules-one that provides for involuntary disposition of issues prior to trial only upon a showing that there are no debatable issues of fact-simply denies the reality that we cannot afford to decide every case based on the fullest possible information. Nourishing the fiction that justice is a pearl beyond price has its own price. ${ }^{62}$ The attempt to escape the necessity of making explicit cost-benefit judgments about procedure merely leads to evasive techniques like managerial judging that invite judges to narrow issues in an ad hoc fashion without safeguards.

To improve the issue-narrowing capacity of our present proce-

(o Fed. R. Crv. P. 56(c).

61 See, e.g. Stiglitz, Information and Economic Analysis: A Perspective, Hoover Institution Working Papers in Economics, Dec. 1984.

23 See generally G. Calabresi \& P. BobbitT, Tragic Choices (1978) (discussing reasons that society may choose to insist that certain values are "pearls beyond price" while compromising them in practice). 
dural system, we need to fill the gaping hole that now exists between the overly scrupulous standard for summary judgment and the essentially standardless procedures of managerial judging. If judges were permitted to find, from a preliminary assessment of the merits, that further development was unlikely to be worth its cost, narrowing of issues might be less arbitrary. The authority to make cost-benefit judgments about additional discovery arguably now exists under rule 26 as amended in $1983 .{ }^{63}$ It will be interesting to see whether judges and litigants will use these provisions to narrow issues based on explicit consideration of whether additional information will be cost-effective.

In the long run, however, having judges make explicit costbenefit decisions about the probable value of developing certain issues is almost certainly only a second-best solution. We would almost certainly do better by structuring a procedural system in which the incentives presented to private litigants and their attorneys rewarded the kind of behavior that we as a society wish to encourage, rather than depending on judges to detect undesirable behavior and repress it after the fact. ${ }^{64}$

\section{The Evolving Functions of Managerial Judging}

In inception, managerial judging was a response to a perceived need by judges to narrow issues if litigation was to be processed in a reasonably efficient fashion. Managerial judging has spread rapidly from one judge to another because many trial judges share a sense of frustration at the amorphous sprawl of litigation under the Federal Rules and are anxious to try new ways of bringing cases to issue. ${ }^{65}$ :

To say that managerial judging arose originally as a way of narrowing issues is not to say, however, that issue-narrowing is ei-

es FED. R. Crv. P. 26(b)(1)(a) ("The . . . extent of use of the discovery methods . . shall be limited by the court if it determines that . . . (iii) the discovery is unduly burdensome or expensive, taking into account the needs of the case, the amount in controversy . . . and the importance of the issues at stake in the litigation.").

- See Note, supra note 21, at 359-60 (arguing that the costs of judicial monitoring of discovery abuse may outweigh the benefits, so that monitoring is a "second-best" solution). In theory, however, it is possible that judicial judgments will be better than private decisions by a sufficient margin to compensate for the additional monitoring costs (if judges are, for example, better able to assess the probable value of further investigation of issues because they are more "objective" than litigants and their attorneys).

${ }^{8 B}$ Cf. Elliott, Holmes and Evolution: Legal Process as Artificial Intelligence, $13 \mathrm{~J}$. LEGAL STUD. 113, 142 (1984) ("Acting alone, no judge makes law; law is a function of legal systems, in which judges communicate and are infuenced by one another. The interesting issue is not why an individual judge decides as he does, but why others follow."). 
ther its permanent or only function. On the contrary, once a legal idea or practice wins acceptance, it takes on a life of its own. Every established legal doctrine or technique becomes part of the raw material that judges can adapt creatively to new contexts. Like other forms of lawmaking, procedural lawmaking under the Rules Enabling Act ${ }^{68}$ rarely invents something entirely new. Rather, creative change is much more frequently accomplished by adapting an existing legal form to a new purpose. ${ }^{67}$

Only shortly after it achieved undisputed legitimacy, ${ }^{88}$ the institution of managerial judging has begun to undergo such a transformation. Managerial judging is evolving rapidly from a set of techniques for narrowing issues to a set of techniques for settling cases.

Describing the shift in the functions of managerial judging in terms of evolutionary metaphors is not meant to imply that it is inevitable that the change will occur. Changes in the law only seem inevitable when we look back at history, knowing the outcome; at the time, it is often not clear which of two contending values is the "stronger" and will prevail." ${ }^{6 \theta}$ What makes the shift in the functions of managerial judging particularly interesting is that the outcome is still "up for grabs." In terms of evolutionary metaphors, a new "mutant" has just appeared on the scene, but it is unclear whether it will die, survive, or become dominant and crowd out its predecessors.

Judges are just beginning to acknowledge openly that "encouraging" settlement is one of the governing principles behind their managerial choices. For example, in the recent Agent Orange case, Judge Weinstein stated that one of his major reasons for certifying the case as a class action was to put more pressure to settle on the defendants and the federal government. ${ }^{70}$ On the other hand, other

6828 U.S.C. \& 2072 (1982).

67 For example, the 1983 amendments to the Rules, which provided sanctions for abusive discovery requests, see FrD. R. Crv. P. 26(g), adapted to a new context the same basic approach that had previously been used (without much success) to deal with refusals to comply with discovery requests, see FrD. R. Crv. P. 37. Another example of the process is the summary jury trial, see supra note 36 , which adapts the established institution of jury trial to the new function of settlement mediation.

68 The 1983 amendments to rule 16(a) were intended to make "case management an express goal of pretrial procedure." FrD. R. Crv. P. 16(a), 1983 advisory committee note. Prior to the 1983 amendments, the legal status of managerial judging was more suspect. See, e.g., Padovani v. Bruchhausen, 293 F.2d 546 (2d Cir. 1961) (Clark, J.) (reversing order precluding testimony following repeated failures to comply with pretrial orders).

so Cf. Holmes, supra note 4, at 449 (describing the "struggle for life among competing ideas, and . . . the ultimate victory and survival of the strongest").

${ }^{70}$ See In re "Agent Orange" Product Liability Litigation, 100 F.R.D. 718, 721 
judges, including some staunch advocates of managerial judging, oppose the use of managerial powers to encourage (or, some would say, to coerce) settlement..1

The evolution toward greater use of managerial judging techniques to encourage settlement was predictable, if not inevitable. At base, the powers of managerial judging are the powers to impose costs, and thereby to increase the price of exercising the powers delegated to attorneys by the Federal Rules of Civil Procedure. There is good reason to believe, however, that the cost of litigation is one of the critical factors that affect decisions to settle. ${ }^{72}$ Thus, to the extent that managerial judging increases costs-and perhaps alters their timing and distribution as well ${ }^{73}$-managerial judging can cause some cases to settle that would otherwise go to trial. ${ }^{74}$

(E.D.N.Y. 1983) ("Third, certification may encourage settlement of the litigation."); id. at 723 ("Finally, the court may not ignore the real world of dispute resolution . . . . [A] classwide finding of causation may . . . enhanc[e] the possibility of settlement among the parties and with the federal government.").

71 See, e.g., Peckham, supra note 12, at 264 ("Professor Resnik is quite right to emphasize that a trial judge must never attempt to use his or her influence to coerce the parties into stipulations or settlement.").

72 See Posner, An Economic Approach to Legal Procedure and Judicial Administration, 2 J. Legal Stud. 399, 418 (1973); Priest, Selective Characteristics of Litigation, 9 J. LEGAL STUD. 399, 401-02 (1980).

Much of the law-and-economics literature models the decision to settle straightforwardly as a function of the relationship between litigation costs and expected outcomes at trial. Elsewhere I have suggested that this view is too simplistic, because a "variety of norms in addition to rational self-interest in the narrow economic sense may enter into decisions to settle or litigate." Elliott, supra note 2, at 65-66. However, even if my position is correct, litigation costs still may be a substantial factor influencing settlement decisions, and therefore changing litigation costs might be expected to produce settlements in cases which otherwise would be litigated.

73 See supra note 22 . It is difficult to predict the effect of the distribution of costs between attorneys and clients-since we do not yet know whether the attorneys' incentives to settle are more important in inducing settlements than are the clients', or vice versa.

14 Professor Resnik correctly points out that even prior to the rise of managerial judging, "the vast majority of cases ended without trial." Resnik, supra note 8, at 385 (citing Clark \& Moore, supra note 51, at 1294) (study showed that $70 \%$ of all civil cases filed in federal court did not reach a judge or jury decision). In 1984, the comparable figure was 95\%. Administrative Office of the U.S. Courts, 1984 Annual Report of the Director 152 (Table 29) (showing that 12,080 civil cases reached trial out of 241,753 civil cases terminated (excluding land condemnation cases), and showing steady decline in the percentage of cases reaching trial (from $8.4 \%$ in 1975 to $5 \%$ in 1984)); see also Galanter, Reading the Landscape of Disputes: What We Know and Don't Know (And Think We Know) About Our Allegedly Contentious and Litigious Society, 31 UCLA L. REv. 4, 28 (1983) (in 10 courts studied, only $9 \%$ of civil cases went to trial).

It is hard to know whether this change is significant. It is not necessary that a majority of cases be tried for trials to have a significant influence on the settlement process. At some point, however, trials may (have) become so rare that they no longer play a significant role in forming the settlement expectations of lawyers and litigants. Cf. Ellickson, Of Cattle and Coase: Dispute Settlement in a Rural California County, 38 Stan. L. REv. 623 (1986) (em- 
Once managerial judging became established, it was inevitable that some judges would begin using their discretionary power to impose procedural costs on particular litigants to stimulate settlements that they considered to be in the interest of justice. However, these uses of the managerial powers of judges and masters to promote settlements are controversial ${ }^{75}$ - and it is important to understand why. Ultimately, procedure and substance cannot be divorced: no procedural decision can be completely "neutral" in the sense that it does not affect substance. Increasing litigation costs does not merely increase the likelihood of settlement; it inevitably alters the amount that a rational party would be willing to pay to settle, and hence is likely to alter the terms of settlement as well. ${ }^{76}$

It is true that litigants must ultimately accept a settlement "voluntarily" as in their best interests, but their choices are inevitably constrained by the shape of the playing field. ${ }^{77}$ When the shape of the playing field is not determined in advance, but altered by discretionary choices made by managerial judges for the purpose of encouraging settlement, it is at least debatable whether the essential conditions for procedural justice are satisfied. ${ }^{78}$

On the other hand, in some circumstances changes in incentives as a result of managerial judging may promote just outcomes. For example, if there is a pronounced difference in the economic resources available to the parties to a lawsuit, a judge might very

pirical study of private dispute settlement suggesting that changes in formal legal rules of liability do not affect actual settlements).

${ }_{75}$ See, e.g., Peckham, supra note 12, at 264; Resnik, supra note 8, at 424-31.

7o See Miller, An Economic Analysis of Rule 68, 15 J. LgGal STud. 93, 105-06 (1986); Priest, Regulating the Content and Volume of Litigation: An Economic Analysis, 1 SUP. CT. EcoN. Rev. 163, 171-73 (1982) (considering the distributive effects of rule 68 offers of judgment).

${ }_{77}$ See Fiss, Against Settlement, 93 YALE L.J. 1073, 1076-78 (1984).

Professor Fiss points out that the advocates of ADR ("alternative dispute resolution") often imagine a typical case as a "quarrel between two neighbors," a model which assumes "a rough equality between the contending parties." Id. at 1076. Fiss and other opponents of $\mathrm{ADR}$, on the other hand, typically imagine a court case in terms broadly suggestive of Brown v. Board of Education. Fiss, Out of Eden, 94 YALE L.J. 1669, 1670 ("it would be nice if the blacks in Chicago . . . did not have to go to court in order to obtain all the Constitution promises, and instead were able to work things out with the school board").

Both models contain elements of truth, but neither is entirely accurate. Courts in our society are charged with processing a wide variety of disputes, and it is doubtful that any single case can typify litigation in general. Rather than argue about which oversimplification is more inaccurate, we should recognize that modern litigation involves a broad spectrum of different kinds of disputes, and therefore that we need a variety of different processes. See Bush, Dispute Resolution Alternatives and Achieving the Goals of Civil Justice: Jurisdictional Principles for Process Choice, 1984 Wrs. L. Rev. 893; Sander, Varieties of Dispute Processing, 70 F.R.D. 111 (1976).

78 See John Rawls, A Theory or Justice 11-22 (1970). 
well promote a more just solution by restricting the ability of the wealthier parties to use their economic resources to tactical advantage. Similarly, if many years are required before a case can go to trial and a successful plaintiff will not be fairly compensated for the time-value of money in the interim, settlements will be discounted to reflect the expected value of delay in the case. A "voluntary" settlement on these terms is not necessarily just. If managerial judging shortens the queue of cases waiting for trial, the terms of settlement may shift toward a more just outcome.

Like every other form of procedural change, managerial judging inevitably will affect the substance of settlements. It remains to be seen, however, under what conditions the direction of the change will be toward more just resolutions of controversies.

\section{Managerial Judging: An InTERIm Assessment}

The jury is still out on managerial judging. Managerial judging is a relatively recent innovation in the history of Anglo-American civil procedure, at least if we mean by managerial judging the selfconscious restructuring of procedural incentives by trial judges on an ad hoc basis to achieve certain objectives.

Critics of managerial judging, such as Professor Resnik and Judge Posner, rightly point out that we lack sufficient data to evaluate conclusively whether, on balance (after the costs of managerial judging are taken into account), managerial judging creates net benefits by increasing the overall efficiency of civil litigation as a mechanism for resolving disputes. ${ }^{79}$

But what the critics (and the supporters) generally have overlooked is that managerial judging can be justified not only in terms of reducing the procedural costs of civil litigation generally, but also by showing that managerial judging improves the quality of substantive justice received by litigants in particular cases. We lack sufficient data to make a definitive assessment of whether on balance managerial judging does in fact increase the quality of substantive justice. One of the crying research needs in civil procedure is for empirical studies of how managerial judging actually works in practice. Nonetheless, as the basis for an interim assessment, in this section I want to suggest several reasons for thinking that, at least in certain categories of cases, managerial judging may contribute to the "just, speedy, and inexpensive determination" of

79 See Resnik, supra note 8, at 417-24; Posner, supra note 37, at 367, 393; see also supra note 39. 
civil actions ${ }^{80}$ not because it reduces expense and delay in the system generally, but because it yields results which are more "just" to litigants.

\section{A. Substantive Versus Procedural Justice}

"Justice" has two faces: one procedural, the other substantive. To date, the discussion of managerial judging has centered almost exclusively on procedural justice. For example, in her 1982 article, Professor Resnik focuses primarily on the loss of procedural fairness that allegedly occurs when judges use certain managerial techniques, such as ex parte, off-the-record status conferences. ${ }^{\text {81 }}$

It is important to keep separate two different objections to Professor Resnik's argument. The first objection distinguishes between the loss of procedural fairness that may accompany the misuse of particular techniques which are incidental to managerial judging, on the one hand, from the loss (if any) of procedural fairness which is inherent in managerial judging by its very nature. Since Professor Resnik's article appeared in 1982, a virtual consensus has developed that ex parte, off-the-record status conferences are inappropriate (at least if one of the parties prefers the conferences to be on the record). No one would suggest today that such discussions with the judge are a necessary ingredient for successful managerial judging.

The second objection to Professor Resnik's position is more fundamental, however. It concedes there may indeed be some costs associated with managerial judging in terms of a loss of real or perceived procedural fairness. But, the second position maintains, these costs can be more than compensated for by the increased quality of substantive justice that results when managerial judging techniques are applied appropriately.

Looking first at whether certain costs are inherent in managerial judging itself, it seems clear that, as I have already conceded, managerial judging does run the risk of real or perceived arbitrariness. ${ }^{82}$ Inherent in managerial judging are two sources of arbitrari-

so Fed. R. CIv. P. 1.

In my opinion, it is not a valid objection that managerial judging is being used to bring about settlements in lieu of trial. See Sarokin, Justice Rushed is Justice Ruined, 38 RutGers L. REv. (forthcoming 1986). The proper question is whether managerial judging enhances the "just, speedy, and inexpensive determination of every action," FED. R. Crv. P. $I$ (emphasis supplied), not whether managerial judging increases or decreases the likelihood of trial.

81 See Resnik, supra note 8 , at $390,426-27$.

s2 See supra note 60 and accompanying text. 
ness. First, in order to be effective, managerial decisions must be made by judges at a stage when they have only a cursory understanding of the merits of cases gathered from pleadings and status conferences. Judges may believe that they know more about the merits of a case than they really do. Moreover, this tendency is likely to be exacerbated over time as lawyers adapt to managerial judging and seek to manipulate it for their own tactical purposes.

The second inherent aspect of managerial judging which may reduce procedural fairness results from its ad hoc character. Because the rules of the managerial judging "game" are not announced in advance and because litigants rarely receive reasoned explanations for managerial (as opposed to legal) rulings, managerial decisions may be perceived as unfair.

But the admission that there are costs to managerial judging in terms of real or perceived procedural unfairness should not by itself be dispositive. The proper issue is whether the benefits of managerial judging in enhancing substantive justice exceed its costs. $^{83}$ At least in certain categories of cases, $I$ believe that the benefits of managerial judging in enhancing substantive justice can exceed the costs in terms of procedural justice, and therefore I favor the judicious use of managerial judging despite the potential for arbitrariness which it admittedly entails.

\section{B. Managerial Judging and Substantive Justice}

In my opinion, the strongest case for managerial judging rests on the proposition that, if used judiciously, managerial judging may improve the quality of substantive justice received by some of the large proportion of litigants who settle their cases prior to trial.

In order for managerial judging to improve the justness of settlements, four conditions must be satisfied:

(1) Litigation must entail relatively significant process costs ("transactions costs");

${ }^{\text {ss }}$ It is difficult, to be sure, to balance procedural and substantive justice, as I have suggested we must. But in weighing procedural changes, the obligation to balance these incommensurable absolutes is inescapable. Many, indeed perhaps all, aspects of our procedure fail to maximize procedural fairness; at some point, we sacrifice that value in order to achieve other goals, such as more just outcomes or lowier administrative costs. The obligation to make trade-offs is particularly intense where procedural and substantive conceptions of justice collide. It is at least conceivable that situations may exist in which the price of a procedure which enhances one person's sense that he has been treated fairly by the state is a result which is grossly unfair to another person in terms of substance. The best case for managerial judging, I believe, arises in cases where there is a strong tension between procedural and substantive justice. 
(2) These process costs must affect the terms on which parties settle cases;

(3) Judges must be capable of detecting circumstances in which the existence of significant process costs introduces distortions into settlements; and

(4) Judges must be capable of imposing offsetting, countervailing costs which cause actual settlements to approach more closely the ideal settlements that would have been reached in the absence of significant process costs.

Conditions (1) and (2) are axiomatic: litigation is surely costly (although there may exist some claims so large that process costs are not great in relation to the amounts in dispute). Similarly, it also seems self-evident that the terms of settlements will be affected at least to some degree by the distribution of process costs in litigation. ${ }^{84}$ Conditions (3) and (4) are more debatable. How well judges can detect and counteract the effects of process costs on the merits of settlements probably varies widely from case-to-case, as the following discussion illustrates.

\section{Transaction Costs and Settlements}

Imagine, for a moment, that we were designing a system of civil procedure for a hypothetical "perfect" world in which there were no transactions costs. ${ }^{85}$ Imagine that everyone had perfect information and therefore knew for certain what was in his best interests. Assume further that agents always acted solely for the benefit of their principals: that lawyers only served their clients, and that judges only served the public. Finally, assume that the process of litigation itself was costless: that a case could be prepared and tried to conclusion without costs in time or money to either the parties or society.

Of course, such a world does not and could not exist. But I take it that if it did exist, there would be no need for managerial judging. If lawyers and clients always knew their best interests and acted on them, and if litigation imposed no costs either on the parties or on society generally, judges could comfortably leave the tasks of preparing and trying cases to lawyers. In such a world, lawyers and clients would either settle cases or try them to conclu-

s4 Thus, it is at least intuitively plausible that I would be willing to accept $\$ 4$ million in settlement on a $\$ 5$ million claim if $I$ could receive it today, rather than five years from now, and if $I$ could save $\$ 600,000$ in attorneys fees in the process. See also supra note 76.

${ }^{\text {s }}$ Cf. Coase, The Problem of Social Cost, 3 J.L. \& Econ. 1 (1960) (describing hypothetical bargaining without transaction costs). 
sion when it was in their best interests (and the best interests of society generally) for them to do so. ${ }^{86}$

The affirmative case for managerial judging depends, then, on the fact that in the real world, as opposed to this imaginary "perfect" world, at least three different types of transactions costs do exist: (1) lawyers and judges do not always act as the perfect representatives of their principals, thus creating "agency costs"; (2) the process of suing itself involves "litigation costs" for the parties; and (3) litigation may impose "externalities" or costs on society generally. It remains to be determined whether managerial judging is capable of addressing problems created by these three types of costs.

1. Agency Costs. The unspoken premise for much of the rhetoric justifying managerial judging is that lawyers do not always act in the best interests of their clients. It is a canon of faith among the proponents of managerial judging, for example, that many lawyers spend too much of their time and their clients' money in pretrial discovery.

The developing theory of principal-agent relationships provides strong reasons to believe that this may indeed be the case. As a general matter, if a principal lacks good information to monitor the inputs supplied by his agent, the agent may have strong incentives to supply either too much or too little of his services. ${ }^{87}$ It is intuitively plausible that clients may generally lack the information and expertise necessary to assess their lawyer's performance accurately, particularly during pretrial preparation. Even in the best of situations, where sophisticated in-house counsel monitors the efforts of outside counsel, it is unlikely that clients can accurately assess whether the benefits to the client of additional pretrial preparation exceed the costs. In-house lawyers generally lack the familiarity with the details of litigation strategy that would be necessary to second-guess the recommendations of outside counsel. Moreover, decisions by in-house lawyers are themselves embedded in a system of organizational incentives that make it unlikely that in-house lawyers will systematically override the judgments of outside counsel, even if those judgments are not in the best inter-

${ }^{88}$ An interesting question is whether disputes would arise in the first place in a hypothetical world of perfect information and no transaction costs. Unfortunately the fascinating question of what factors cause civil disputes is outside the scope of this article.

${ }^{87}$ See generally Baiman, Agency Research in Managerial Accounting: A Survey, $1 \mathrm{~J}$. Acct. Literature 154, 163 (1982) (describing so-called "moral hazard" problems in terms of the principal's inability to develop information to monitor his agent's performance). 
ests of the client.

In theory, then, it is conceivable that managerial judging might enhance the quality of civil justice in some cases by protecting clients from the excesses of their own lawyers, who may wish to expend more resources on a particular matter than is in the client's best interest. By imposing compensating costs on lawyers (such as threatening them with sanctions, or requiring them to seek leave of court before posing long sets of interrogatories), managerial judging might, in theory, correct for problems in the structure of incentives between lawyers and clients that cause lawyers to over-prepare (or under-prepare) to the detriment of their clients.

It should be noted, however, that in order for managerial judging to improve the quality of justice in this way, judges must be in a better position to second-guess the resource allocation decisions made by lawyers than are clients. It is possible that sometimes judges may indeed have a perspective on a case that enables them to see which preparations lawyers legitimately need to undertake and which they should pass by, but judges may also think that they understand more about a case than they actually do. Consequently, correcting for this particular type of agency cost problem provides at best a dubious justification for managerial judging. In general, managerial judging can counteract problems of resource allocation in litigation if, but only if, judges are better able to monitor lawyers' preparation decisions than are clients.

On the other hand, in other types of agency problems, the prognosis for managerial judging may be more positive. For example, suppose that a plaintiff in a personal injury case is risk averse because she is confined to a wheelchair for life, and her only substantial asset is a tort claim with only a thirty percent chance of success before a jury. Suppose further, however, that if she is successful, a very large award is likely. This might be the case, for example, if damages are clear but liability is not. Suppose also that the plaintiff's lawyer has a personal stake in the outcome by virtue of a contingent fee arrangement, and that the lawyer has a portfolio of personal injury cases over which he (unlike his client) can spread the risk of an unfavorable result. If so, then the lawyer's best interests during settlement negotiations are not necessarily congruent with those of his client. ${ }^{88}$

s8 The example in the text is based on a hypothetical posed by Judge Manuel L. Real at the Conference of Metropolitan District Chief Judges, Monterey, California, March 25, 1986.

It is debatable whether it is technically correct to characterize the client as risk averse 
In such a case, if the trial judge has sufficient experience in evaluating personal injury cases and sufficient information about the state of settlement negotiations, then the judge might correctly deduce that, by holding out for an unrealistically high settlement amount, the plaintiff's counsel is not acting in his client's best interests. Particularly when the counsel is inexperienced or inadequate, there will be a strong incentive for the judge to intervene in order to remedy the situation. How the judge should do so is debatable, but at least some judges might mention the results in other similar cases in open court in the presence of the client, thereby bringing substantial pressure on the plaintiff's lawyer to settle. If the judge is right in his or her evaluation of the case and of the dynamics of settlement negotiations, the settlement that results may be more just than what would have occurred without judicial intervention.

2. Litigation Costs. A second set of circumstances that may justify managerial judging arises when litigation is unnecessarily costly not because of what one's own lawyer does, but because of what other parties do. There is no question that the expense and delay of litigation creates manifold opportunities for strategic manipulation by adversaries. Again, in theory, judges may be able to enhance the overall quality of justice if they are able to identify and repress strategic manipulation of costs and delay. But here again there is some question about the ability of judges to distinguish between appropriate use of the resources of an adversary system and inappropriate abuse of those resources. For much the same reasons that judges may not be able to protect clients from too much discovery by their own lawyers, judges may also be unable to protect them from too much discovery by opposing counsel. In addition, if judges are willing to second-guess litigants' tactical decisions, another level of procedure is created which is itself subject to strategic manipulation.

For example, suppose that a defendant clearly owes $\$ 5$ million on a contract but refuses to pay, based on a prediction that it will take years of discovery and motions practice before the case

and the lawyer as risk preferring, since their differing attitudes are based not on their tastes for risks in the abstract, but on differences in their circumstances. Other theoreticians, however, emphasize that one's circumstances shape one's tastes, including one's appetite for risk. Regardless of whether the concept of risk aversion is technically proper in this situation, the fact remains that due to the differences in their circumstances the lawyer is more likely than the client to be willing to "roll the dice" by refusing to settle in order to have a chance at obtaining a very large jury verdict. 
reaches trial. ${ }^{89}$ If a managerially-inclined judge is able to determine accurately what is really involved in such a case, he or she could readily bring to bear pressure that might result in a more just settlement than would have occurred in the absence of intervention. The judge could, for example, set the case for trial within a few weeks and/or threaten to impose sanctions on the defendant and defense counsel if the defense proved frivolous. There is a substantial risk, however, that a managerial judge will wrongly diagnose a case as frivolous and take actions of this type when they are not appropriate. ${ }^{00}$

3. Externalities. The argument for managerial judging based on externalities is predicated not on the costs of litigation to the immediate parties, but on the costs to members of society who are not parties to the case. When the parties do not bear all the costs of their actions, they may have an incentive to consume resources in litigation even though those resources might be put to better use elsewhere in society.

Here again, it is theoretically possible that managerial judging might increase overall social justice. If judges are able to detect gross abuses of resources which are out of all proportion to their social benefits, they may be able to improve the welfare of society by overriding private decisions as to the level of expenditures on litigation which are appropriate. But there is again the countervailing danger that judges may think that a case is more clear-cut than it actually turns out to be. It is interesting to ponder how many developments in the law might have been stifled at their inception if judges had possessed general, unreviewable authority to dispose of cases as unworthy of being brought.

\section{An Assessment}

Several different conclusions emerge from the foregoing examples. First, it should be clear that not all cases are alike; some present far more compelling circumstances for managerial judging than others. Similarly, not all techniques that are loosely grouped together under the rubric "managerial judging" are equally appropriate or defensible. To improve the quality of managerial judging, we need to develop a more sophisticated understanding of the characteristics of cases that make them appropriate candidates for

so The example in text is based on a hypothetical suggested by Judge H. Lee Sarokin at the Conference of Metropolitan Chief Judges, Monterey, California, March 25, 1986.

so See, e.g., supra note 44. 
particular managerial techniques.

In all three of the categories that I have proposed (agency costs, litigation costs, and externalities), it is conceivable that managerial judging may improve the quality of justice. Whether managerial judging will actually have that effect, however, depends primarily on how accurately judges are able to detect and remedy particular distortions in incentives created by process costs. While in particular cases managerial judging may achieve results that are more just than would passive judging, there is no reason to be confident that judges will be able to perform this function consistently well.

The fundamental weakness in managerial judging is its ad hoc, flexible character. The basic premise for managerial judging is that the effects of incentives for socially inappropriate behavior in litigation can be overcome by designing counteracting incentives on a case-by-case basis. This approach has the understandable appeal of necessity to the judges who are faced with the task of dealing with individual cases in which they see what they consider to be gross abuses. But as a comprehensive strategy for dealing with the effects on inappropriate incentives in litigation, managerial judging is more stopgap than final solution.

\section{ConcLusion}

The differences between the processes of legal change and biological evolution are at least as illuminating as the similarities.

Managerial judging is like the "panda's thumb" in that both represent the adaptation of an existing structure to perform new functions. However, the poor panda is probably stuck with its funny little "thumb," even though it is a far from perfect solution to the panda's needs; provided that the "thumb" works well enough that not too many pandas starve, nature is unlikely to evolve a new structure which represents a fundamentally different approach to the problem.

Procedural systems, on the other hand, are like other artificial systems designed by human beings: they can evolve, but they can also be redesigned consciously. Because human beings can learn, we need not, at least in theory, remain the captives of the historical developments that have brought us to a particular point. There is no necessity that the future of civil procedure must. consist of the continued evolution of managerial judging. On the contrary, there are strong reasons to believe that more fundamental design changes in the existing system of procedural incentives might be more desirable than the continued evolution of managerial judging. 
First, the ad hoc nature of managerial judging imposes certain inherent limitations. In the short run, those limitations can be ameliorated somewhat by developing guidelines to assist judges in making managerial decisions. These guidelines should be based on analysis of successful managerial judging. We need to develop a better understanding of what characteristics of cases make them good candidates for particular managerial techniques. The newly revised Manual for Complex Litigation ${ }^{91}$ represents a sound first step in this direction, although it is deficient in that it generally avoids the controversial and central issue of the judge's role in promoting settlement.

In the long run, however, the disadvantages that arise from the ad hoc character of managerial judging cannot be eliminated, only reduced. More fundamental reform must proceed by addressing directly the system of incentives that creates the need for managerial judging in the first place. ${ }^{92}$ Redesigning incentives with an eye to their effect on the terms of settlements will not only reduce the arbitrariness which is inherent in managerial judging, but will also be more likely than ad hoc intervention by judges to encourage just outcomes. For example, if the existing methods of compensating counsel do in fact create powerful economic incentives for lawyers to act in ways that are not in the best interests of their clients, restructuring the compensation system directly is more likely to be effective than managerial techniques. Similarly, if defendants are encouraged to delay judgment because of rules of law that deny successful litigants the full time-value of money during the pendency of litigation, restructuring the system of incentives is more likely to be successful than is an overlay of counterincentives imposed on an ad hoc basis by managerial judges.

Reforming procedural incentives to promote just settlements requires a fundamental change in the way that we view civil procedure. Before such changes can be made, we will have to stop thinking of the "pretrial" process as a prelude to trial, and start thinking of it as the "main event"-as the matrix of incentives within which the overwhelming majority of cases are going to be settled by two party-appointed arbitrators (the opposing lawyers). The most pervasive "ADR" system in the United States today is proba-

21 Manual ror Complex Litigation, Second \& 20 (1985).

23 See Rosenberg, The Federal Rules After Half a Century, 36 Marne L. Rev. 243, 248 (1984) ("Rather than devise additional rules propelled by threats of sanctions and penalties, a modern procedural system should try to develop incentives and rewards of positive kinds to encourage lawyers to act in harmony with the system's goals."). 
bly pretrial procedure under the Federal Rules of Civil Procedure, but this system has been designed with little or no attention to its effect on the terms of settlement.

If this fundamental change in the way that we think about civil procedure eventually does come about, the shift in the functions of managerial judging which is currently evolving will be in part responsible. At least since Savigny, lawyers have understood that case-by-case development is the law's way of engaging in exploratory behavior-of discovering problems and trying out approaches to solve them. Codifying rules and statutes come later, after greater understanding has developed. ${ }^{93}$

Seen in this light, the evolutionary shift in the functions of managerial judging from narrowing issues for trial to altering incentives for just settlements marks a major new direction in procedural development. We should recognize managerial judging as a significant new trend in the evolution of procedure, not its final stage. ${ }^{94}$

os See Friedrick yon Savigny, Of the Vocation of our Age gor Legislation and JuRISPRUdence (A. Hayward trans. London 1831 \& Arno Press reprint 1975); see also Elliott, supra note 2, at 40-43 (discussing Savigny's theories).

* Recently, certain scholars have argued that in the long run American civil procedure is likely to become more like its Continental European counterparts-less adversarial and "lawyer-dominated" and more centered on "judicial fact-gathering." See, e.g., Langbein, The German Advantage in Civil Procedure, 52 U. CHL. L. REv. 823 (1985); Brazil, The Adversary Character of Civil Discovery: A Critique and Proposals for Change, 31 VAND. L. REv. 1295, 1298-1303 (1978). While predicting the future is always treacherous, I do not share this vision.

Even assuming that less "adversarial" systems of procedure possess inherent "advantages" (a large assumption), it does not follow that the existence of these advantages guarantees the ultimate acceptance of a less adversarial system in the United States. Particularly where a large and powerful constituency (lawyers) exists to maintain the present system, the relevant question is not whether the existing system is optimal, but whether it can be made satisfactory. Moreover, I believe that maintaining party control but modifying the structure of incentives is more consistent with our country's prevailing ideology of market capitalism (with limited state intervention to modify incentives), which emphasizes private initiative rather than state control. 